\title{
Welfare words: Critical social work \& social policy
}

\author{
Paul Michael Garrett \\ SAGE Publications, London, England, 2018 \\ ISBN 978-1-4739-6897-4, pp. 270, paperback, NZD54.77
}

$\mathrm{P}$ aul Garrett's book, entitled Welfare Words: Critical Social Work \& Social Policy, is a book about collective narratives that underpin the provision of assistance to people in need. At the time of publishing this book, Paul Garrett was a Senior Lecturer in the School of Political Science and Sociology at the National University of Ireland, in Galway. His previous writing includes books on social work and social theory, and child protection social work, with a focus on neoliberal reform and marginalisation.

Garrett's book critically examines the language of welfare to enable consideration of the historical, political and cultural standpoints that underpin welfare discourses. Through employing the phrase "Welfare Words" he invites us to analytically examine (or re-examine) the power and motivations contained within welfare discourses. Garrett provides the reader with an insightful consideration of the role of language in social welfare service provisions. The book succeeds in clearly demonstrating how neoliberal ideology oppresses and blames and, in doing so, it dispels neoliberal discourse -challenging the reader to reframe the language of oppressive practice norms.

Garrett states that, in the United Kingdom (and elsewhere), a form of neo-welfare has developed, with a focus on managing welfare provision sufficient to maintain social stability, the privatisation of public welfare provision, precarious working conditions, and enhanced conditionality and surveillance of those receiving welfare. This includes algorithmic monitoring and the othering of populations. When considering the situation in Aotearoa New Zealand, social bonds have been piloted to raise money to provide services for people with mental health issues to return to the workforce, and the Ministry of Social Development is using data to conduct predictive modelling to target at-risk citizens. The line between beneficiaries and the working poor has become increasingly slim, and recipients of welfare services (especially beneficiaries) are a stigmatised group who are under surveillance. Welfare reforms have been used to construct meaning and advance agendas about people and groups who are perceived, through the use of neoliberal language, to be lacking or deficit. A classic example of this is illustrated in a National Party press release to promote benefit sanctions before an upcoming, 2017, election. The National Party Spokesperson for Social Development (2017, para.10) stated "...one in five beneficiaries tell us that drug use is a barrier to them getting a job - so we are increasing the support we give them to kick drug use and get work ready." Myths about beneficiaries as drug users, benefit fraud being a significant problem, and falsehoods such as being on a benefit is a 'lifestyle choice' constantly resurface in Aotearoa New Zealand (New Zealand Council of Christian Social Services, n.d.), just as they do in the United Kingdom. In our current socioeconomic climate of increasing poverty and economic exclusion, there is an urgent need to scrutinise the way in which welfare words are spoken to advance political agendas.

Garrett acknowledges that the inspiration for this book came from Raymond Williams' (1983) text Keywords: A Vocabulary of Culture 
and Society. This text contains a set of essays that critique how political values shape our understanding of the world through considering the way in which words such as 'liberal' and 'underprivileged' are used within society. Garrett has chosen seven keywords and phrases to dissect in his book Welfare Words, these are: "welfare dependency"; "underclass"; "social exclusion"; "early intervention", "resilience"; "care"; and "adoption". The book's introductory chapter which outlines the aims of the book, considers how neoliberalism has shaped welfare provisions. Garrett states that he has arranged Chapter Two as a conceptual chapter, to allow for increased engagement with the chosen welfare words. After setting the conceptual scene, there is then a chapter written about each of the chosen keywords, with a concluding chapter to bring all the threads together.

Garrett states in his introductory chapter that, through this book, he hopes to reach out across disciplines so that his work stimulates critical conversations in final year and postgraduate students. To encourage these conversations, each chapter utilises "Reflection and Talk boxes" to stimulate discussion and critical questioning. I have used the introductory chapter of this book as a set reading in a fourthyear paper to aid with the critical revision of workplace norms and institutionalised language that students experienced while on field placement. Ironically, some of the students commented that Garrett's academic writing style made the meaning of his work difficult to grasp, with some student feedback indicating that they had to read the chapter multiple times to fully appreciate the meaning of his words. The chapter assisted students with breaking down how dominant discourses shaped the context of their field placement experiences, thus enabling them to gain a deeper understanding of the power of language in social work practice.

The words that are preferred by dominant groups to underpin language about welfare may not always be overt in their "welfare bashing" rhetoric, but perhaps they are more destructive as they divert attention away from poverty and inequality and making it harder for solutions to be found. This text is a refresher for us all, a reminder to consider the social constructions and agendas that sit behind the words that we adopt in everyday practice.

\section{References}

New Zealand Council of Christian Social Services. (n.d.). Facts about poverty in New Zealand. Retrieved from https://nzccss.org.nz/work/poverty/facts-about-poverty/

National Party. (2017). More support and obligations for unemployed youth [Press release]. Retrieved from https://www.national.org.nz/more_support_and_ obligations_for_unemployed_youth

Williams, R. (1983). Keywords: A vocabulary of culture and society (2nd ed.). New York, NY: Oxford University Press. 